\title{
Opportunities, Challenges and Countermeasures of SMEs Based on "Inner Cycle"
}

\author{
Rui Ge \\ Office of International Cooperation and Exchange, Huaiyin Institue of Technology, Huai'an 223001, Jiang Su, China \\ DOI: $10.32629 /$ memf.v2i6.589
}

\begin{abstract}
Over a long time, the development of China's economy has always relied heavily on investment, export and consumption, or is export-oriented to promote economic growth; however, in the new world economic situation, the export has been curbed and the economic focus needs to be shifted. And China has gradually formed the awareness and strategy of attaching importance to stimulating domestic demand and expanding the domestic consumption market. Therefore, internal circulation will bring unlimited opportunities and challenges to SMEs. It is necessary for SMEs to pay attention to internal circulation and formulate corresponding countermeasures according to internal circulation policies to promote the stable and sustainable development of SMEs.
\end{abstract}

Keywords: internal circulation, small and medium-sized enterprises, opportunities, challenges, countermeasures

\section{Introduction}

The current global economy is very sluggish. In order to cope with the new world economic situation, China has proposed an important policy of a dual cycle of internal and external economic cycles. The economic internal cycle has a greater impact on small and medium-sized enterprises. China has a large-scale consumer market and a complete production chain, and has an important foundation for the formation of an internal cycle. With the domestic cycle as the theme, it is necessary to continuously expand domestic demand, promote effective investment, maintain and improve the domestic industrial chain and supply chain. Therefore, for small and medium-sized enterprises, opportunities and challenges coexist under the economic internal cycle. Small and medium-sized enterprises must be clear about their own positioning, clarify where the opportunities and challenges are reflected, and develop coping strategies that can grasp the dual-cycle policy to help small and medium-sized enterprises, which will contribute to SMEs to go out of their troubles.

\section{Background of internal circulation}

At present, our country has begun to implement a dual-cycle policy based on internal recycling, which is a necessary measure in line with the current trend of China's economic development. Over the past 30 years of reform and opening up, China has opened up the economic situation by external circulation, and in the future it will gradually take the internal circulation as the leading factor. In the past decades of non-circular development, China's imports and exports have grown from a proportion of less than $10 \%$ of the country's GDP to $64 \%$ in 2006 . Around 2010, China's total import and export trade ranked first in the world, GDP second in the world.

At present, China needs to adjust the economic model of the past external circulation. The main underlying reason is the changes that have occurred in the past ten years. The first is that the 2008 global financial crisis has weakened the import and export capacity of Europe and the United States, and the growth of China's exports has also encountered pressure; the second is that from 2006 to 2015, when China's exports have increased in increments, the growth potential has gradually weakened. The third is the turning point of China's labor force after 2012. Since then, the annual retired population in China is higher than the new labor force, leading to the increase in labor prices; the fourth is the increase in the price of oil, electricity and gas, and the cost of land.

\section{The current survival status of SMEs}

The current global economic situation is more diversified, and it is an era of coexistence of challenges and opportunities for the domestic economy. According to the official data, China's GDP growth rate for the four quarters of 2020 is $-6.8 \%$ in the first quarter, $-9.7 \%$ in the previous quarter, $3.2 \%$ in the second quarter , $4.9 \%$ in the third quarter, the fouth quarter $6.5 \%$, and the annual economic growth rate was $2.3 \%$. From these data, it can be seen that 2020 is the lowest year in the past years.

In the background of the new internal circular economy, the key role and status of SMEs will be highlighted. Small and 
medium-sized enterprises account for $80 \%$ of the total number of enterprises in the country, and the labor force employed by small and medium-sized enterprises accounts for $70 \%$ of the total labor force in the country. Small and medium-sized enterprises are supporting large industrial clusters and can solve major livelihood issues such as employment. Only by guaranteeing the development of SMEs can most of the grassroots enterprises be stabilized. The primary power source of the internal cycle is the enterprise, and small and medium-sized enterprises are the main force in the enterprise. Small and medium-sized enterprises can seize the opportunities and meet the challenges under the internal cycle to promote the prosperity and development of the local economy.

\section{Opportunities and challenges faced by SMEs}

Companies in all walks of life are divided into large, medium and small. This article takes medium-sized companies, DLS auto parts company in the manufacturing industry, as the starting point for analysis. DLS Auto Parts Co., Ltd. covers an area of more than 50,000 square meters. The company was established in 1979 and currently has more than 400 employees. It is a joint-stock enterprise specializing in the production of automobile, engine, internal combustion engine parts and highstrength standard parts.

\subsection{Opportunities of small and medium-sized enterprises}

Opportunities are in-depth opening up to foregin coutries. Dual circulation is a new development pattern in which internal circulation is the mainstay and domestic and international dual circulations promote each other. The domestic tax and fee preferential policies and the support of lean manufacturing concepts will provide DLS companies with a solid backing and create an excellent internal environment. DLS companies cannot ignore the rare opportunities at the moment, and they must achieve rapid growth in the next few years. Quality development requires a keen sense of smell and rush forward.

Industry chain resource integration, investment creates opportunities. As a growth company, DLS has great development potential, and investment strategy, as an important part of its development, has a non-negligible impact on the company's future value creation.

\subsection{Challenges faced by SMEs}

Financial book loss, poor performance. The financial risks faced by private manufacturing companies are increasing. At the beginning of the new year in 2019, listed private manufacturing companies burst into thunder. In 2020, small and medium-sized enterprises will be worse off, and many private companies will suffer serious losses. For many listed private manufacturing companies, the IPO was the peak of the company's development that year, and then financial problems broke out one after another.

For companies, poor capital flow will often bring financial risks. During the epidemic, China has more relaxed financing policies for small and medium-sized enterprises, but bank loans are a double-edged sword as the break of the capital chain will cause dilution of control or loss of control. The vicious circle of lending cannot rely on the incremental funds generated by business or investment activities to cope with the problem of capital turnover with its own cycle.

On the other hand, when banks approve loans, they assess that private small and medium-sized enterprises have relatively high loan risks and require harsh mortgages. They only accept land use rights and real estate as collateral. Small and medium-sized enterprises have few mortgages and it is difficult to obtain bank loans smoothly. Their market competitiveness is weak, their profitability is very low and only in the cracks can they urvive. The market competitiveness and the growth of SMEs is weak.

\section{Specific countermeasures for SMEs under internal circulation}

\subsection{Bringing together outstanding talents and implementing reasonable system}

Use the connections of internal employees, mobilize all staff, make good use of the company's "live advertising", seek outstanding talents for the company, work hand in hand, forge ahead, and push the company on the fast lane of rapid development.

Carry out the company-wide rationalization proposal and reward system to optimize the process, and maintain a high degree of consistency with the company's vision.

\subsection{Broadening sources of income with technology and tapping profit growth points}

DLS is at the back end of the automobile industry chain, and its direct customers are all automobile manufacturers or enterprises above designated size. These enterprises are industry leaders with relatively good capital flow, attach importance 
to contract and trustworthiness, and their payments are generally on time. From the perspective of broadening source income, companies should try their best to find more high-quality customers to replace customers with low scores and poor cooperation status.

\subsection{Introducing a strategic cost management system to reduce costs}

Enterprises should strengthen management and plan carefully to avoid waste in procurement, logistics, production and administrative management. The technical quality departments are supposed to organize technicians to try to improve the process, optimize the process, apply for patents to form its own intellectual property rights, and effectively increase the production capacity of machinery and equipment and the utilization of labor hours. Activity-based costing and value chain cost management systemIntroduce shoudl be introduced to effectively reduce the direct and indirect costs of products.

\subsection{Seeking policy support from government and using the bonuses of preferential policies}

The manufacturing industries supported and encouraged by the state are the foundation of making a country stronger if our country would like to achieve the long-term goal of Industry 4.0 in 2035. Since the epidemic in 2020, the state has issued a number of preferential policies to support small and medium-sized enterprises. Small and medium-sized enterprises should make good use of policies and obtain support from relevant government departments. Small and medium-sized enterprises should also enhance their own management and manufacturing levels, obtain various certification standards and qualifications, upgrade to enterprises above designated size, apply for technology warehousing enterprises, include major new products in the guiding catalog, apply for patents, and allow self-developed patented products to export for foreign exchange and introduce new methods and qualified persons to enterprises.

\section{Conclusion}

The internal circulation is not only a new policy of our country, but a new opportunity for SMEs. However, in the face of new opportunities, new challenges cannot be ignored. Only when opportunities and challenges are both attached importance to can they enjoy the dividends of the policy, and SMEs can occupy more market share of the internal circulation.

\section{References}

[1] Lu Minfeng, Xu Yangyang. Opportunities, challenges and growth points of small and medium-sized enterprises under the background of economic double cycle[J]. Southwest Finance. 2021, (01): 105-122.

[2] Wang Rong. The crisis and countermeasures of private small and medium-sized enterprises under the new crown pneumonia epidemic[J]. Journal of Sichuan Institute of Socialism. 2020, (01): 48-54.

[3] Xue Yan. Research on the development of small and medium-sized enterprises and financial support under the economic double cycle[J]. National Circulation Economy. 2020, (30): 73-82.

[4] Zhang Xingxiang, Zhuang Yajuan, Huang Mingliang. Research on the Mirror Image and Breakthrough Path of China's Manufacturing Industry in the Global Value Chain - Based on the Perspective of the New Development Pattern of "Double Cycle"[J]. Humanities Magazine. 2020, (11): 72-82. 